\title{
WestVirginiaUniversity
}

THE RESEARCH REPOSITORY @ WVU

West Virginia Agricultural and Forestry Experiment

Davis College of Agriculture, Natural Resources

Station Bulletins

And Design

$1-1-1955$

\section{Custom rates for farm jobs in West Virginia}

G. E. Toben

Paul E. Nesselroad

Follow this and additional works at: https://researchrepository.wvu.edu/ wv_agricultural_and_forestry_experiment_station_bulletins

\section{Digital Commons Citation}

Toben, G. E. and Nesselroad, Paul E., "Custom rates for farm jobs in West Virginia" (1955). West Virginia Agricultural and Forestry Experiment Station Bulletins. 371.

https://researchrepository.wvu.edu/wv_agricultural_and_forestry_experiment_station_bulletins/365 @ WVU. It has been accepted for inclusion in West Virginia Agricultural and Forestry Experiment Station Bulletins by an authorized administrator of

The Research Repository @ WVU. For more information, please contact ian.harmon@mail.wvu.edu. 
West Virginia University Libraries

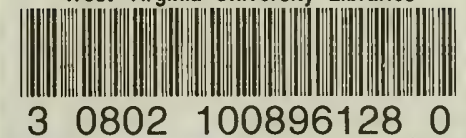


Digitized by the Internet Archive in 2010 with funding from

Lyrasis Members and Sloan Foundation 


\section{Summary}

Custom work generally includes the services of the machines, the power, and an operator. The majority of the custom rates are on an hourly basis. Some differences in rates were found between areas of the State. However, most of the area differences were associated with various kinds and sizes of implements.

Custom work for jobs done with two horses varied from $\$ .75$ to $\$ 2.50$ an hour. The rates most commonly charged were $\$ 1.00$ and $\$ 1.50$. These rates covered the charge for the team, machine, and man.

More custom jobs were done with tractors than with animals. There was a tendency for an increase in custom rates with an increase in the size of the tractor. When low-cost implements were used with small tractors the more common rates per hour were $\$ 2.00$; with medium size tractors they were $\$ 2.50$ and with large size tractors they were $\$ 3.00$. When high-priced implements were used, higher rates were used. The listings of the rates by jobs are shown in the tables.

WEST VIRGINiA UNIVERSITY

Agricultural Experiment Station

College of Agriculture, Forestri, and Home Economics

H. R. VARNeY, Director

MORGANTOWN 


\section{Contents}

\section{INTRODUGTION}

REASON FOR THE STUDY ............. 5

Amount and Size of Custom Work ....... 5

Location OF FARMERS INTERVIEWED ......... 5

Commercial Gustom Operators $\ldots \ldots$.

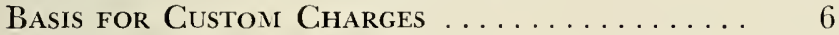

Explanation of Common Rate

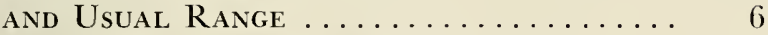

Basis for Hotrly and ACRe Rates ........ 7

TILLAGE JOBS

PlowING $\ldots \ldots \ldots \ldots \ldots \ldots \ldots \ldots \ldots \ldots \ldots$

Discing $\ldots \ldots \ldots \ldots \ldots \ldots \ldots \ldots \ldots \ldots \ldots \ldots \ldots \ldots$

Harrowing $\ldots \ldots \ldots \ldots \ldots \ldots \ldots \ldots \ldots \ldots \ldots$

DragGING $\ldots \ldots \ldots \ldots \ldots \ldots \ldots \ldots \ldots \ldots \ldots$

CORN JOBS

Corn Planting $\ldots \ldots \ldots \ldots \ldots \ldots \ldots \ldots \ldots \ldots . \ldots 9 . \ldots \ldots$

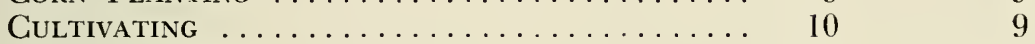

Corn Picking $\ldots \ldots \ldots \ldots \ldots \ldots \ldots \ldots \ldots \ldots \ldots 10 \ldots \ldots$

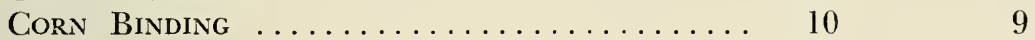

Corn SHrEdDIng $\ldots \ldots \ldots \ldots \ldots \ldots \ldots \ldots \ldots \ldots \ldots 10 \ldots \ldots$

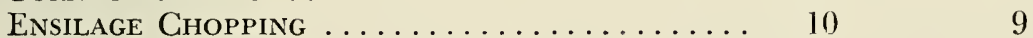

SMALL GRAINS

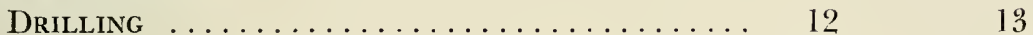

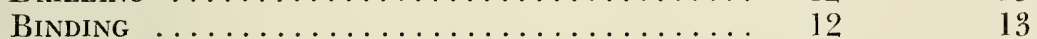

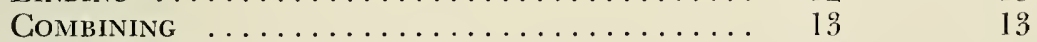

Threshing $\ldots \ldots \ldots \ldots \ldots \ldots \ldots \ldots \ldots \ldots \ldots \ldots$

HAY HARVESTING

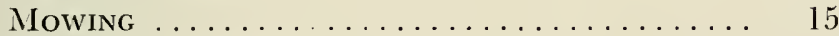

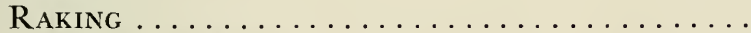

Complete Harvest ............... 15

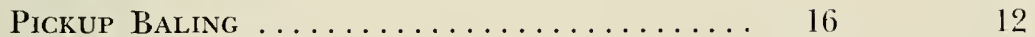

Stationary Baling $\ldots \ldots \ldots \ldots \ldots \ldots \ldots \ldots \ldots 16 \quad 17$

\section{MISGELLANEOUS JOBS}

SHEEP SHEARING

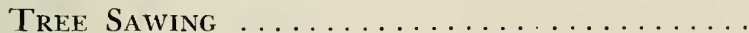

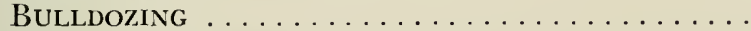

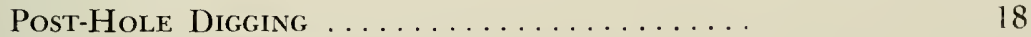

HAULING $\ldots \ldots \ldots \ldots \ldots \ldots \ldots \ldots \ldots \ldots \ldots \ldots \ldots \ldots \ldots$

SPRAYING $\ldots \ldots \ldots \ldots \ldots \ldots \ldots \ldots \ldots \ldots \ldots \ldots$ 



\section{Custom Rates For Farm Jobs In West Virginia}

G. E. TOBEN AND P. E. NESSELROAD*

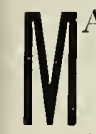

ANY West Virginia farmers do not own all the farm machinery used on their farms. Some exchange work with neighbors to get the jobs done. Others hire someone to do the job.

When farm jobs are done on a hired basis, there are problems of agreeing on the pay rates. Many of the rates are decided on the basis of the rates others are using. Questions about rates used by others are frequently directed to West Virginia University. To answer these questions and to provide farmers and others with a basis for establishing rates, 466 farmers were visited. These farmers were selected at random within cacl of 13 different laming areas of West Virginia. The location of the 45 magisterial districts in which these farmers live is shown in Figure 1.

Some area differences in rates were found; however, most of these are reflected in different kinds and sizes of implements. Small implements are more common on the hillside farms. The one-horse operations are used on steep slopes and for small jobs. Larger implements are used on land that is less rolling.

Most custom work was between neighbors. Many farmers who did jobs for others made definite statements that the jobs were considered as favors to neighbors. They preferred not to do work off the farm. Others indicated that they did a small amount of custom work each year. The tables in this bulletin show that most jobs were small and that the work done by custom operators was also limited.

Only one farmer within the sample indicated that he made a business of custom work with all his equipment. Four other farmers considered custom work a business with one of two specialized implements. The implements were a baler, lime spreader, post hole digger. and bulldozer. All farmers visited were asked for the names of known people who made a business of doing custom work on farms. Only a few such persons were located.

*G. E. Toben is Associate Professor of Agricultural Economics and Associate in Farm Management in the West Virginia University Agricultural Experiment Station. P. E. Nesselroad is an Assistant in Farm Management. 


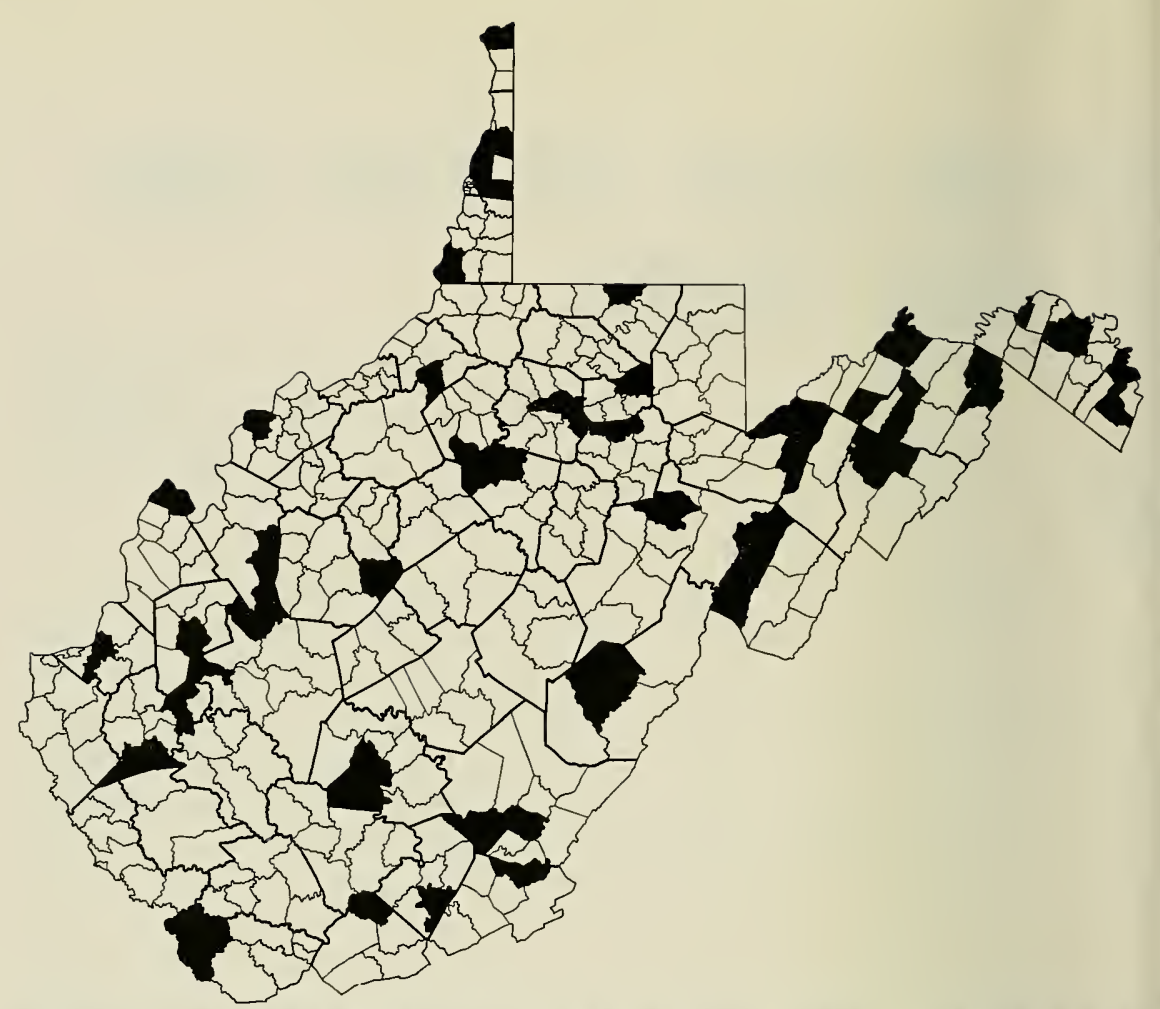

FIGURE 1. FARMERS interviewed in survey were located in 45 magisterial districts throughout the State. (The districts are indicated by black shading.)

Farmers contacted in this study were asked to provide information about the custom work they performed or hired done on their own farms. In some cases this procedure resulted in double reporting on the same job. Information on custom work between neighbors was also included whenever the farmer interviewed knew the details.

Custom rates usually include a charge for the machine, either horse or tractor power, fuel when tractors are furnished, and one operator. For some harvesting jobs a crew of men is furnished by the custom operator. For these situations the size of crew is reported. In other instances the charge includes materials, such as twine and spray, which are generally used with the job.

The rates reported are those used by fammers in 1951. They include the most conmon rate and the usual range. $\Lambda$ rate reportod ats "most common" is a specific rate used in more than 25 per cent of the reported cases. When two different rates are reported by more than 25 per cent of the cases, both rates are shown as common rates. The one occurring more frequently is given first. The usual ranges include at least 80 per 
cent of the rates. In many instances it shows all rates reported. In no instance does it exclude more than 10 per cent of the cases at either the lowest or highest end.

Most of the jobs were done on an hourly basis. This is understand. able because the conditions under which jobs are done in a hilly and mountainous state vary considerably. The differences in field conditions and size of jobs influence the accomplishment in a given time. Rates reported on a daily basis were converted and reported in terms of hourly rates.

Some jobs were done on an acreage basis. Most of these cases are also reported. This provides an opportunity to compare the rates per hour and per acre.

Farmers may use the reported rates as guides in setting custom rates. As they are used, it must be remembered that rates may change with time. Rates on very common jobs will be set within each locality in line with local conditions. Rates for less common jobs can be set by adjusting rates shown in this bulletin in accordance with the rates for common jobs.

Rates will also vary with the conditions; therefore, it is important to consider the range in rates as well as the most common rates. In using the information also take note of the number of cases reported. When the number of cases is small, more consideration must be given to ranges in rates.

\section{Tillage Jobs}

Plowing is the most common custom job in West Virginia. Thirtythree per cent of the farmers interviewed either hired someone to plow for them or else plowed for a neighbor.

Thirty per cent of all cases of custom plowing were done with one horse or a team. All these rates were charged on an hourly or a daily basis. Daily rates were comparable to the hourly rates. Because of this, all custom horse plowing rates are reported on an hourly basis (Table 1).

One farmer plowed 30 acres for his neighbors with a tean and single bottom plow. The next largest operator plowed nine acres on a custom basis. Sixty-seven per cent of the jobs of plowing with horses were two acres or less.

Only nine cases of custom plowing with tractors were reported on an acre basis. All the other reports on tractor plowing were on an hourly basis. These rates varied with the size of plows. Plowing jobs were generally larger with tractor plows than with horse-drawn plows. One operator reported 200 acres of custom plowing with his two 16-inch 
Table 1. Plowing, Disking, Harkowing, and Dragging Custom Rates in 1951. (Rates Include Machine, Power, and Operator.)

\begin{tabular}{|c|c|c|c|c|c|c|}
\hline \multirow{2}{*}{$\begin{array}{l}\text { JOB AND SIZE } \\
\text { OF IMPLEMENT }\end{array}$} & \multirow{2}{*}{ Power } & \multicolumn{2}{|c|}{ Rate Per Hovr } & \multicolumn{2}{|c|}{$\begin{array}{l}\text { AVERage ACres } \\
\text { of Custom Work }\end{array}$} & \multirow{2}{*}{$\begin{array}{l}\text { NUMBER } \\
\text { OF RATES } \\
\text { INCLUDED }\end{array}$} \\
\hline & & Most COMMON & USUAL RANGE & $\begin{array}{l}\text { DURING } \\
\text { YEAR }\end{array}$ & $\begin{array}{l}\text { PER } \\
\text { JOB }\end{array}$ & \\
\hline Plowing & & Dollars & Dollars & & & \\
\hline Single hillside & 1 horse & 1.00 & $1.00-1.25$ & 3.8 & 1.4 & 14 \\
\hline Single hillside & 2 horses & 1.00 & $0.75-2.00$ & 3.3 & 2.3 & 43 \\
\hline Single bottom & 1 horse & 1.00 & $0.75-1.25$ & 7.0 & 3.9 & 6 \\
\hline Single bottom & 2 horses & 2.00 & $1.00-2.50$ & 10.5 & 2.1 & 26 \\
\hline Single bottom & tractor & 2.00 & $1.25-3.50$ & 7.0 & 4.2 & 44 \\
\hline 2 - 12 -inch & tractor & $3.00 \& 2.50$ & $2.00-4.00$ & 13.3 & 4.8 & 88 \\
\hline $2-14$-inch & tractor & 3.00 & $2.00-4.00$ & 20.3 & 6.0 & 63 \\
\hline 3-bottom & tractor & 3.50 & $3.00-5.00$ & 13.3 & - & 4 \\
\hline \multicolumn{7}{|l|}{ Plank dragging } \\
\hline $\begin{array}{l}5 \& 6 \mathrm{ft} . \\
\text { Harrowing }\end{array}$ & $\begin{array}{l}2 \text { horses } \\
\text { or tractor }\end{array}$ & - & $1.00-2.25$ & 5.0 & 1.0 & 5 \\
\hline Spike tooth & 1 horse & 1.00 & $0.75-1.25$ & 4.0 & 1.9 & 18 \\
\hline Spike tooth & 2 horses & 1.00 & $0.75-2.00$ & 4.8 & 3.1 & 22 \\
\hline $\begin{array}{l}\text { Spring tooth } \\
\text { Disking }\end{array}$ & $\begin{array}{l}2 \text { horses } \\
\text { or tractor }\end{array}$ & 1.50 & $1.50-2.60$ & 5.7 & - & 5 \\
\hline 5 ft. single & 2 horses & 1.00 & $0.75-2.50$ & 4.8 & 1.9 & +2 \\
\hline $\begin{array}{l}5 \mathrm{ft} . \text { single } \\
6 \mathrm{ft} \text {. single }\end{array}$ & $\begin{array}{l}\text { tractor } \\
2 \text { horses }\end{array}$ & 2.00 & $1.50-2.50$ & 10.0 & 2.0 & 7 \\
\hline & or tractor & - & $1.00-2.50$ & - & 3.0 & 6 \\
\hline $8 \mathrm{ft}$. single & tractor & 2.50 & & 20.0 & 7.0 & 2 \\
\hline $5 \mathrm{ft}$. double & tractor & 2.50 & $2.00-4.00$ & 11.7 & 4.8 & 39 \\
\hline $6 \mathrm{ft}$. double & tractor & 3.00 & $2.00-3.50$ & 26.2 & 4.4 & 53 \\
\hline $7 \mathrm{ft}$. double & tractor & 3.00 & $2.00-4.00$ & 22.1 & 13.8 & 35 \\
\hline $8 \mathrm{ft}$. double & tractor & 3.00 & $2.00-4.00$ & 10.4 & 3.0 & 11 \\
\hline
\end{tabular}

bottom plows. The next largest custom operator reported 80 acres. Thirteen per cent of the farmers doing custom plowing accounted for more than 50 per cent of the total acres. The other 87 per cent of the farmers doing custom plowing each turned 20 acres or less for thcir neighbors. The custom jobs that individual farmers hired donc on their farms were generally small. Thirty per cent of the jobs of custom plowing with tractors were two acres or less. Sixty-seven per cent were five acres or less. Only 6 per cent of the individual jobs were over 10) acres.

Twenty per cent of the farmers interviewed either hired somcone to disk for them or else disked for a neighbor. The custom rates for disking varied with the size of disks. One farmer disked 180 acres on a custom basis. Another disked 100 acres. Thirteen per cent of those 
doing the most disking accounted for more than half of the acreage. Each of the rest disked 20 acres or less for neighbors. Sixty-two per cent of them did 10 acres or less.

The largest individual job of disking that was hired was 30 acres. More than 50 per cent of the jobs were seven acres or less and 37 per cent of the jobs were two acres or less.

\section{Corn Planting, Cultivating, and Harvesting}

Only 22 cases of custom corn planting were reported. One of these was planting with one horse and a drill, seven were with a team and two-row planter, and 14 were with a tractor and two-row planter. The rates charged on an acre basis were about the same with tractors as with horses, whereas the rates per hour with tractors were about double those with horses (Table 2). The farmer doing the largest

Table 2. Gorn Planting, Cultivating, and Harvesting Custom Rates in 1951. (Rates Include Machine, Power, and Operator.)

\begin{tabular}{|c|c|c|c|c|c|c|c|}
\hline \multirow{2}{*}{$\begin{array}{c}\text { JOB AND } \\
\text { SIZE OF } \\
\text { IMPLEMENT }\end{array}$} & \multirow[b]{2}{*}{ POWER } & \multicolumn{3}{|c|}{ RAte Per Hour } & \multicolumn{3}{|c|}{ RAte PER ACRe } \\
\hline & & $\begin{array}{c}\text { Most } \\
\text { COMMON }\end{array}$ & $\begin{array}{l}\text { USUAL } \\
\text { RANGE }\end{array}$ & $\begin{array}{l}\text { NO. OF } \\
\text { RATES }\end{array}$ & $\begin{array}{c}\text { Most } \\
\text { Common }\end{array}$ & $\begin{array}{l}\text { USUAL } \\
\text { RANGE }\end{array}$ & $\begin{array}{l}\text { NO. OF } \\
\text { RATES }\end{array}$ \\
\hline Planting & & Dollars & Dollars & & Dollars & Dollars & \\
\hline 2-row planter & 2 horses & 1.50 & $1.00-1.50$ & 3 & - & $1.00-2.00$ & 4 \\
\hline 2-row planter & tractor & 3.00 & $2.50-4.00$ & 6 & 2.00 & $1.33-2.00$ & 8 \\
\hline Cultivating & & & & & & & \\
\hline $\begin{array}{l}\text { Double shovel } \\
\text { 2-row }\end{array}$ & $\begin{array}{l}1 \text { horse } \\
\text { tractor }\end{array}$ & $\begin{array}{l}1.00 \\
-\end{array}$ & $1.25-3.50$ & $\begin{array}{l}2 \\
3\end{array}$ & & & \\
\hline Picking & & & & & & & \\
\hline $\begin{array}{l}\text { 1-row } \\
\text { 2-row }\end{array}$ & $\begin{array}{l}\text { tractor } \\
\text { tractor }\end{array}$ & $\begin{array}{c}5.00 \\
8.00 \& 7.00\end{array}$ & $\begin{array}{c}3.50-7.00 * \\
7.00-8.00\end{array}$ & $\begin{array}{l}8 \\
7\end{array}$ & $\begin{array}{c}6.00 \& 7.00 \\
7.00\end{array}$ & $\begin{array}{c}5.00-10.00 \\
5.00-8.00\end{array}$ & $\begin{array}{r}25 \\
5\end{array}$ \\
\hline Corn Binder & & & & & & & \\
\hline 1.-row** & tractor & 3.00 & $1.50-4.00$ & 7 & 4.00 & $3.50-5.00$ & 4 \\
\hline $\begin{array}{l}\text { Shredding } \\
\text { Chopping }\end{array}$ & tractor & - & $3.50-5.00$ & 2 & & & \\
\hline $\begin{array}{l}\text { Stationary } \\
\text { Field } \hat{\dagger}\end{array}$ & $\begin{array}{l}\text { tractor } \\
\text { tractors }\end{array}$ & 10.00 & $\begin{array}{l}1.25-5.00 \\
9.00-13.00\end{array}$ & $\begin{array}{r}14 \\
8\end{array}$ & - & $1.06-2.50$ & 5 \\
\hline
\end{tabular}

*Usually one wagon is furnished; however, rate differences were not associated with numbers of wagons furnished.

**Two custom operators furnished twine. One charged $\$ 3.00$ an hour; the other, $\$ 4.00$ an acre.

†The rates include field chopper, blower, 2 tractcrs and fuel, 2 men and usually 2 or 3 wagons. 
amount of custom planting put in 40 acres of corn for neighbors. The largest individual job reported was 25 acres; most of the jobs were less than 10 acres.

Most farmers apparently have their own cultivators or use the hoe to tend their corn. Only six cases of custom cultivating were reported. These farmers set their rate on an hourly basis. Three used two-row tractor cultivators and three used one-horse cultivators. One of these was a three-shovel cultivator and the other two were double-shovel cultivators.

Forty-five farmers reported rates for custom corn picking. About one-fourth of the jobs were done with two-row pickers. All the rates included the corn picker, the tractor and fuel, and one man. In most instances one wagon was also furnished. In a few cases two wagons were included, and in a few other cases, no wagons were furnished. The rates per acre with the single- and double-row corn pickers were not materially different. The hourly rates for two-row pickers were more than for single-row pickers, but not double the rate.

Two farmers considered corn picking an important source of income. Each of these picked a total of 300 acres of corn for neighbors. The next largest operator picked 75 acres for neighbors. The rest of the farmers doing custom picking picked fewer acres. Most individual jobs were small. Except for one individual job of 75 acres all other jobs were 30 acres or less. Forty-two per cent of the jobs were 10 acres or less.

All but one of the rates for custom corn binding were in the eastern counties. The largest acreage harvested by any farmer on a custom basis was 30 . Individual jobs were generally small, the majority being less than seven acres.

Three cases of corn shredding were reported. AIl of these were along the eastern border of the State. Each of the rates was different even though all included the shredder, tractor, fuel, and one operator. One rate was 20 cents per bushel of shelled corn. The other two were $\$ 3.50$ and $\$ 5.0()$ an hour.

Custom use with a stationary silage chopper was reported by 21 larmers. All but two of these lived in counties with an castern or western state line border. Two-thirds of the rates were on an hourly basis. The other rates were by the silo, ton, foot of silage, or on an exchange of work basis. There was no consistency in these rates. No two rates within a county or adjoining county were the same.

The size of choppers varied from 12 to 19 inches, with the 14 -inch size being reported in 62 per cent of the cases. Custom rates were not associated with size of cutter. One of the highest rates was charged with 


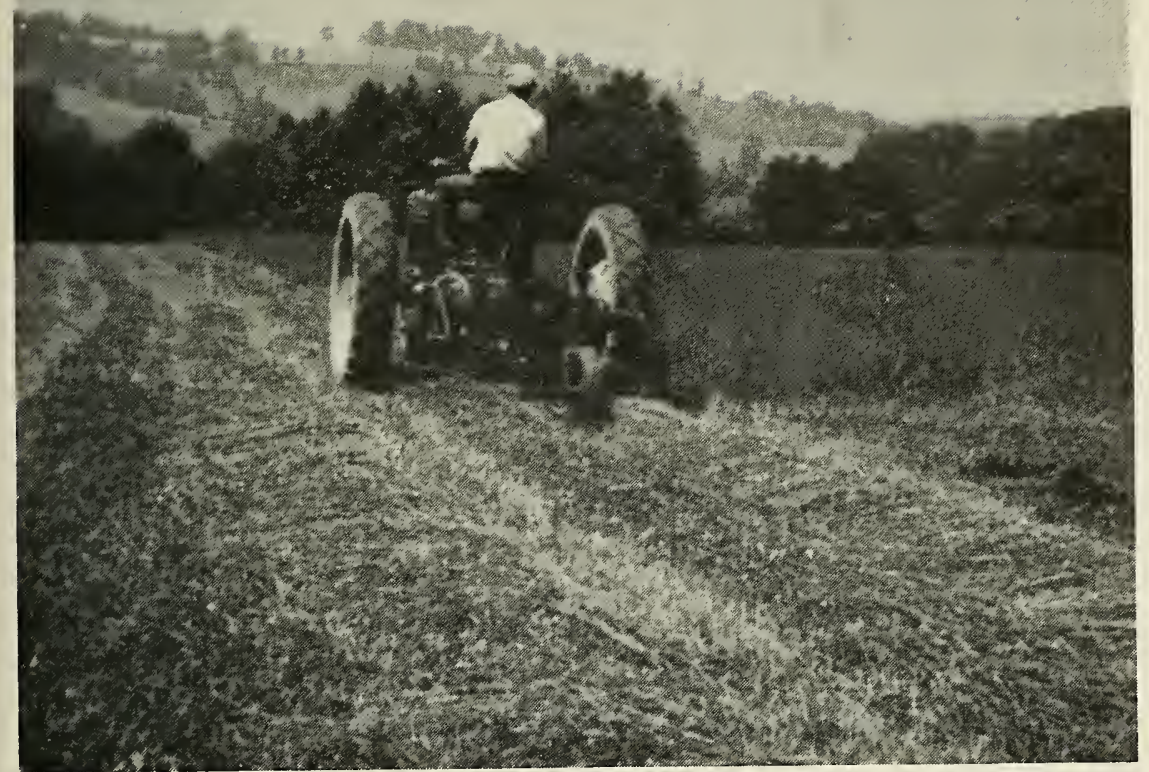

TRACTOR MOWING of hay is one of the common jobs done on the custom basis.

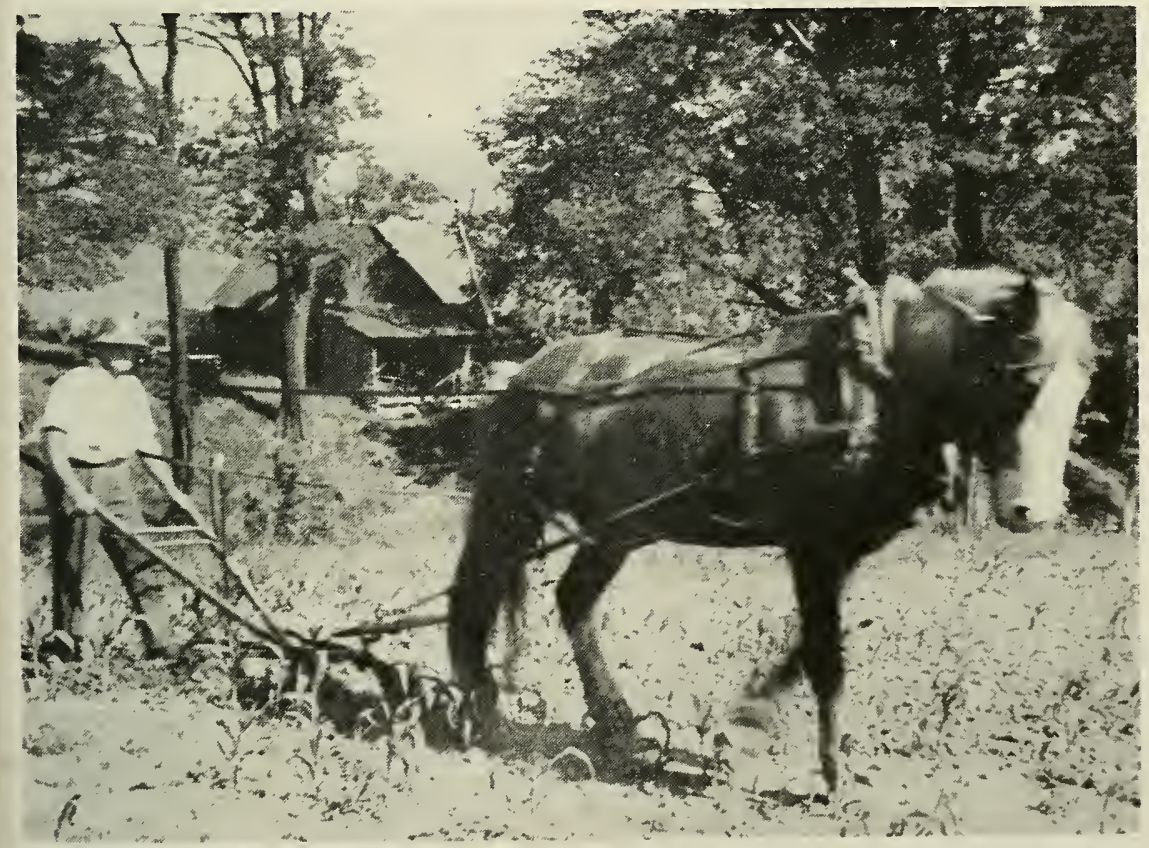

THIS CORN was cultivated with one horse. Same farmer owned pick-up baler. 
the use of a 13-inch chopper. The lowest rate per hour was with a 14-inch machine. In each instance the rate included the chopper, tractor, fuel, and operator. A similar situation occurred when rates were set on a tonnage basis. The lowest rate of 30 cents and the highest rate of 75 cents a ton were both charged with 14 -inch choppers.

Fifteen cases of field chopping were reported. Eight of these were for chopping corn silage and seven for hay silage. The rates reported did not reflect differences between corn and hay silage. As has been the case for other large machine jobs, these rates were reported by farmers living in counties along the east and west borders of the State.

\section{Small Grain Jobs}

There was considerable variation in the arrangements for custom grain drilling. These included rates for the drill alone, the drill with horse and with tractor power, and for charges on the basis of an hour and an acre. So much variation was reported in the rates that only a common rate is reported for drilling witl a tractor on an hourly basis (Table 3). Six out of 10 of these rates were $\$ 2.50$ an hour. In all other instances not more than two rates of the same amount were reported.

Custom drilling was not an important business for any of the farmers. The largest acreage done by one farmer was 25 . Half of the farmers who did custom drilling each seeded less than 8 acres. The largest individual custom job was 12 acres. Two cases were only $11 / 2$ acres in size.

Custom rates for cutting grains with a binder were reported by 31 farmers. Four of these farmers were in Harrison and Randolph Counties. All others were in counties bordering other states. One farmer charged \$2.00 an hour for the use of the binder alone. All other rates included the binder, tractor, fuel, and one operator. In addition to this, all but one rate included either a second man or the trine. Only three rates included both the second man and twine. One of these ras the average rate per acre, and the other two were the highest rates per hour and per acre. There was no evidence in the rates to show that the charge for the second man was either more or less than the charge for the twine.

None of the farmers reporting custom rates for the use of the bincler reported different rates for different grains. Neither was there any difference in rates on an acreage basis for different sizes of binders. The rates, however, did increase with the size of binder when they rere on an hourly basis. The $\$ 2.50$ and $\$ 3.00$ rates per hour were for fiveand six-foot binders. The $\$ 4.00$ and $\$ 5.00$ rates were for eight- and tenfoot binders respectively. The six-foot binder was used in 17 of the 31 cases reported. 
Table 3. Simall Grain Seeding and Harvesting Gustom Rates in 1951. (Rates Include Machine, Poiner, And Operator.)

\begin{tabular}{|c|c|c|c|c|c|c|c|}
\hline \multirow{2}{*}{$\begin{array}{c}\text { JOB AND } \\
\text { SIZE OF } \\
\text { IMPLEMENT }\end{array}$} & \multirow[b]{2}{*}{ Power } & \multicolumn{3}{|c|}{ Rate Per Hour } & \multicolumn{3}{|c|}{ RAte Per ACre } \\
\hline & & $\begin{array}{c}\text { MOST } \\
\text { CoMLMON }\end{array}$ & $\begin{array}{l}\text { USUAL } \\
\text { RANGE }\end{array}$ & $\begin{array}{l}\text { No. OF } \\
\text { RATES }\end{array}$ & $\begin{array}{c}\text { MOsT } \\
\text { COMMON }\end{array}$ & $\begin{array}{l}\text { USUAL } \\
\text { RANGE }\end{array}$ & $\begin{array}{l}\text { NO. OF } \\
\text { RATES }\end{array}$ \\
\hline & & Dollars & Dollars & & Dollars & Dollars & \\
\hline Drilling & 2 horses & - & $1.25-1.50$ & 4 & - & $1.00-2.00$ & 3 \\
\hline Drilling & tractor & 2.50 & $2.00-3.50$ & 10 & - & $1.25-2.50$ & 8 \\
\hline Drilling & none 1 & & & & - & $0.25-1.00$ & 4 \\
\hline Binder 2 & tractor & - & $2.50-5.00$ & 6 & 3.00 & $2.00-4.00$ & 24 \\
\hline Combine & & & & & & & \\
\hline $4 \& 41 / 2 \mathrm{ft}$ & tractor & - & $4.00-5.00$ & 23 & 6.00 & $5.00-7.50$ & 44 \\
\hline $5 \mathrm{ft}$. & tractor & 5.00 & $5.00-6.00$ & 85 & $5.00 \& 6.00$ & $5.00-8.00$ & 156 \\
\hline $6 \mathrm{ft}$. & tractor & - & $3.00-5.00$ & 37 & $6.50 \& 7.00$ & $4.00-8.00$ & $22 \mathrm{~s}$ \\
\hline $7 \mathrm{ft}$. & tractor & 8.00 & & 1 & - & $5.50-7.00$ & 29 \\
\hline $12 \mathrm{ft} .10$ & tractor & 6.50 & & 1 & 5.50 & & 2 \\
\hline
\end{tabular}

1 Nothing but the drill furnished.

2Rates usually include either a second man or twine.

3 The case of $\$ 4.00$ an hour furnished two men.

+ All but one case of $\$ 6.00$ an acre furnished two men.

5 One case of $\$ 5.00$ an hour and the two cases over $\$ 5.00$ furnished two men.

6Two cases of $\$ 6.00$ an acre and 3 of the 4 cases over $\$ 6.00$ furnished two men.

7 One case of $\$ 5.00$ an hour furnished two men.

8 Fifteen cases on an acreage basis include two men. The 7 cases with one man were rates from $\$ 5.00$ to $\$ 7.00$ per acre.

9 The $\$ 7.00$ rate included two men.

10These were seif-propelled; a tractor is not furnished. Two men furnished in all three cases.

Two farmers in the Eastern Panhandle cut a large acreage with a binder on a custom basis. One cut 125 acres and the other 130 acres for neighbors. The remainder of the farmers doing custom grain binding averaged 16 acres each. There were two individual jobs of cutting grain with a binder that were 60 acres each. The next largest job was 18 acres. The majority of the jobs were less than seven acres.

Custom combine rates were reported by 61 farmers. All these farmers, except for one in Randolph County, were in counties on the border of the State. Most of these were using five- and six-foot combines. The smallest combines reported cut a four-foot swath. The largest were 12 -foot combines. There were three of these. All were reported in Jefferson County.

The rates for combining included the combine, power, and labor. The 12-foot combines and one of the seven-foot combines were selfpropelled. In all other cases tractors and fuel were furnished by the custom operator. Eighteen of the combines had an auxiliary motor. The others were operated with the power take-off. One operator was furnished as a part of all rates, and a second man was furnished in 56 
per cent of the cases. It is reasonable to assume that rates were higher when a second man was furnished; however, differences in rates did not show a direct relation with the number of men furnished.

Most cases of custom combining were reported on an acreage basis. One-fourth were by the hour. One toll case was reported. Here the operator took four bushels per acre. All rates were the same with different crops.

Two combine owners did extensive custom combining. One cut 350 acres and the other 400 acres of grains. None of the other operators cut more than 100 acres. Half of those who did custom combining cut less than 25 acres for neighbors. The largest single job of custom combining was 53 acres; the smallest job was 2 acres. More than half of the jobs were from 10 to 20 acres in size.

Many jobs of threshing grain in West Virginia are small. Because of this some threshing machine operators have a minimum charge for each set. These charges were the same for all grains (Table 4). Differences in charges are influenced primarily by area and size of crew. The charge for each set in the three eastern counties of Jefferson, Berkeley, and Morgan was lower than the average for the rest of the State. Some equally low rates were found in other parts of the State; however, the areas were small. The average charge for each set outside

Table 4. Threshing Custom Rates in 1951. (Rates Include Thresher, Tractor, Fuel, and Crew.)

\begin{tabular}{|c|c|c|c|c|c|c|c|}
\hline \multirow{2}{*}{$\begin{array}{l}\text { Kind of Grain and } \\
\text { Basis of Charge }\end{array}$} & \multirow{2}{*}{$\begin{array}{l}\text { SIZE OF } \\
\text { MACHINE }\end{array}$} & \multicolumn{3}{|c|}{$\begin{array}{l}\text { RATES IN JEFFERSON, BERKE- } \\
\text { LEY, AND MORGAN COUNTIES }\end{array}$} & \multicolumn{3}{|c|}{ Rates in Rest of State } \\
\hline & & $\begin{array}{c}\text { MOST } \\
\text { COMMON }\end{array}$ & $\begin{array}{l}\text { USiAL } \\
\text { RANGE }\end{array}$ & $\begin{array}{l}\text { No. OF } \\
\text { RATES }\end{array}$ & $\begin{array}{c}\text { Mlost } \\
\text { Comion }\end{array}$ & $\begin{array}{l}\text { USUAL } \\
\text { RANGE }\end{array}$ & $\begin{array}{l}\text { No. OF } \\
\text { RATES }\end{array}$ \\
\hline & & Dollars & Dollars & & Dollars & Dollars & \\
\hline \multicolumn{8}{|l|}{$\begin{array}{l}\text { Minimum set charge } \\
\text { for all grains }\end{array}$} \\
\hline $\begin{array}{l}\text { One man } \\
\text { furnislied }\end{array}$ & any & & & & - & $5.100-10.00$ & 4 \\
\hline $\begin{array}{l}\text { 'To men } \\
\text { furnisherl }\end{array}$ & any & $7.001 \& 8.00$ & $6.610-8.100$ & $\tau$ & 10.000 & $8.00-15.610$ & 24 \\
\hline $\begin{array}{l}\text { Three men } \\
\text { furnished }\end{array}$ & & & & & 15.60 & $10 .(10)-15.00$ & $\tau$ \\
\hline Wheat per bu. & $22 "$ & & & & $0.10 \& 0.08$ & $0.08-0.12$ & 56 \\
\hline Oats per bu. & $\begin{array}{l}28^{\prime \prime} \\
22^{\prime \prime}\end{array}$ & $0.07 \& 0.08$ & $0.06-0.08$ & 23 & $\left|\begin{array}{c}0.12 \& 0.10 \\
0.08\end{array}\right|$ & $0.07-0.15$ & 40 \\
\hline . & 28 & 0.05 & & 5 & $\begin{array}{l}0.08 \\
0.08\end{array}$ & $\begin{array}{l}0.06-0.10 \\
0.07-0.10\end{array}$ & 11 \\
\hline Barley per bu. & $22^{\prime \prime}$ & & & & 0.10 & $0.09-0.12$ & 4 \\
\hline & $28 "$ & $0.0 \mathrm{~T}$ & & 3 & 0.10 & $0.09 \cdot 0.12$ & 4 \\
\hline $\begin{array}{l}\text { Wheat and oats toll } \\
\text { charge per } 100 \mathrm{bu} \text {. }\end{array}$ & any & & & & $\begin{array}{l}\text { Bushels } \\
7 \& 8\end{array}$ & $\begin{array}{l}\text { Bushels } \\
6-121 / 2\end{array}$ & 18 \\
\hline
\end{tabular}


of the three eastern counties was $\$ 7.50$ with a one-man crew. It averaged $\$ 10.50$ with two men and $\$ 13.00$ with three men.

Most of the set charges included the threshing of a specific quantity of grain. Above this quantity the bushel rates applied. The quantity generally included in the set charge was 100 bushels. In some instances the minimum amount was lower.

The average size of jobs where set charges were made was 151 bushels. More than 50 per cent of the jobs were less than 100 bushels.

The bushel rates for threshing did not vary with the size of the crew furnished by the operator. The rates were different for different kinds of grain. They were consistently lower in the three eastern counties.

The average size of a wheat threshing job in the three eastern counties was 432 bushels. Seventy-five per cent of the jobs were below this average in these three counties. In the rest of the State the average job was 231 bushels. Twenty-eight per cent of wheat jobs outside of the eastern counties were less than 100 bushels.

\section{Hay Harvesting}

Except for plowing, hay mowing is the most common job done on a custom basis. In general the rate increased with the size of the mower (Table 5). For most of the haying jobs, there were two common rates; that is, two different rates were widespread enough for each to be reported by more than 25 per cent of the farmers.

Individual jobs were generally small, with 50 per cent being less than 10 acres. Some farmers who did mowing for others helped several

Table 5. Hay Harvesting Custom Rates in 1951.

(Rates Include Implement, Potwer, and One Man.)

\begin{tabular}{|c|c|c|c|c|c|c|c|}
\hline \multirow{2}{*}{ Machine } & \multirow{2}{*}{ POWER } & \multirow{2}{*}{$\begin{array}{c}\text { BASIS } \\
\text { OF } \\
\text { CHARGE }\end{array}$} & \multicolumn{2}{|c|}{ Custom Rate } & \multicolumn{2}{|c|}{$\begin{array}{l}\text { AVERAGE ACRES } \\
\text { OF CUSTOM WORK }\end{array}$} & \multirow{2}{*}{$\begin{array}{l}\text { Number } \\
\text { of Rates } \\
\text { INCLUDED }\end{array}$} \\
\hline & & & $\begin{array}{c}\text { MOST } \\
\text { СоMMON }\end{array}$ & $\begin{array}{l}\text { USUAL } \\
\text { RANGE }\end{array}$ & $\begin{array}{l}\text { DURING } \\
\text { YEAR }\end{array}$ & $\begin{array}{l}\text { PER } \\
\text { JOB }\end{array}$ & \\
\hline & & & Dollars & Dollars & & & \\
\hline Mower & team & hr. & 1.00 & $0.75-2.50$ & 13 & 9 & 47 \\
\hline Mower- $-41 / 2 \mathrm{ft}$. & tractor & hr. & $1.50 \& 2.00$ & $1.50-3.50$ & $\therefore 4$ & (i & 7 \\
\hline Mower $-5 \mathrm{ft}$. & tractor & hr. & $2.00 \& 2.50$ & $1.50-4.00$ & $\therefore 9$ & 7 & 10 \\
\hline Mower- $6 \mathrm{ft}$. & tractor & hr. & $2.00 \& 2.50$ & $2.00-4.00$ & $: 37$ & 13 & 65 \\
\hline Mower $7 \mathrm{ft}$. & tractor & hr. & $3.0 n$ & $2.00-4.00$ & $: 37$ & 13 & 34 \\
\hline Mower & tractor & acre & $1.00 \& 2.00$ & $1.00-2.50$ & 55 & 13 & 9 \\
\hline 1)ump rake & team & hr. & - & $1.00-2.00$ & 15 & 8 & 16 \\
\hline Dump rake & tractor & hr. & 2.00 & & & & 3 \\
\hline Side delivery & tractor & hr. & $2.50 \& 3.50$ & $2.00-3.50$ & 16 & 11 & 6 \\
\hline Buck rake & tractor & $\mathrm{hr}$. & $2.50 \& 3.00$ & $2.00-5.00$ & & & 11 \\
\hline Complete harvest & & share & $1 / 2$ crop & & 25 & 7 & 9 \\
\hline
\end{tabular}




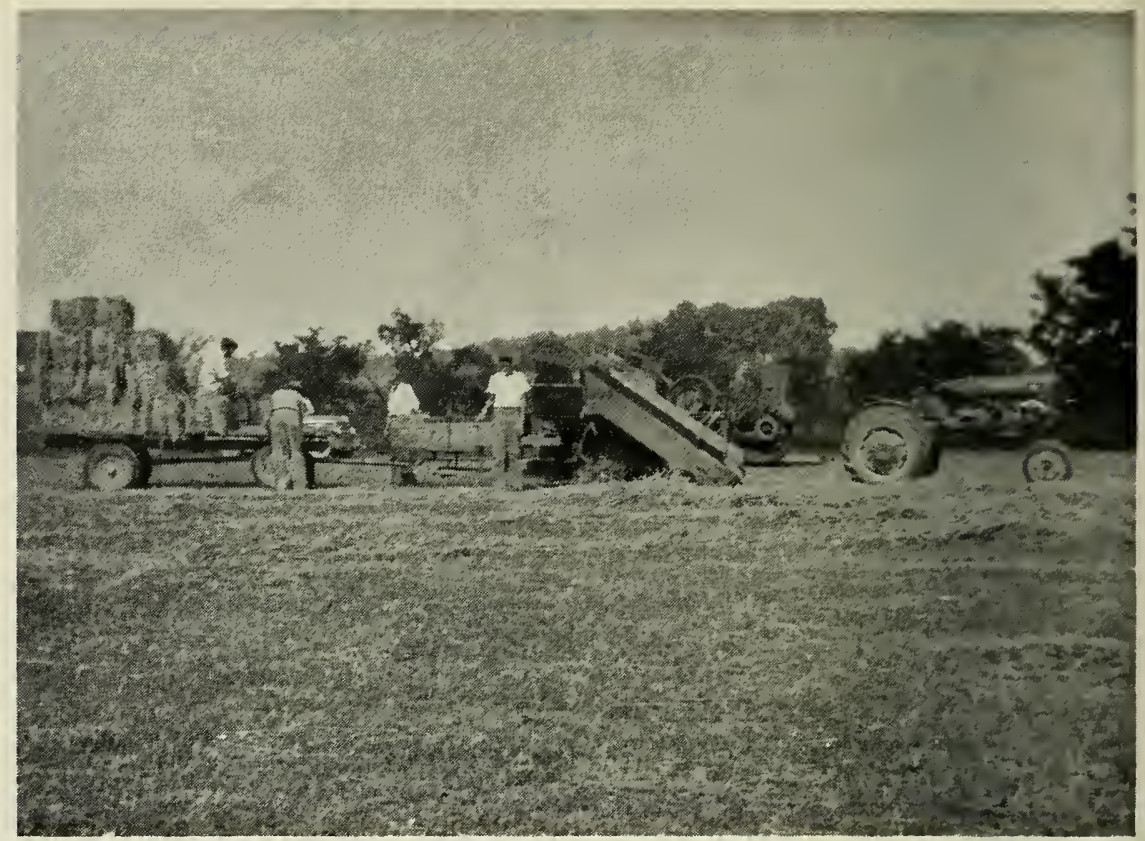

THE FARMER hiring a job done frequently must have a large crew available.

farmers. One did about 200 acres on a custom basis: 20 per cent who did mowing accounted for half the acreage mowed on a custom basis.

The range in custom rates for baling hay with a one-man pickup twine baler was about the same in all parts of the State (Table 6). However, the average rate varied. The rates averaged 11.6 cents per bale in the eastern part of the State, 12.0 cents in the Northern Panhandle, and 13.2 cents in the western counties.

All of the reported jobs of baling in the eastern part of the State were small. They varied from 46 to 560 bales. Some jobs in the rest of the State were also small; however, a greater portion of them were larger. One job was 6,500 bales. The rates with wire balers ran higher than with twine balers. The size of crew included with the stationary baler varied; however, the rates charged did not necessarily vary with the number in the crew.

\section{Sheep Shearing}

Custom sheep shearing was reported by 56 farmers. The rates varied between areas of the State and the kind of power. Differences due to power are shown in Table 7. The counties in the Eastern Panhandle and along Virginia had lower shearing rates than counties in the central and western parts of the State. 
reported with less frequency. Rates for these jobs are reported in Table 8. Most of the jobs reported by only a few farmers were not included in this publication.

Table 8. Custom Rates on Other Jobs. (Rates Include Machine, Power, and One Operator.)

\begin{tabular}{|c|c|c|c|c|c|}
\hline \multirow[b]{2}{*}{ ЈоB } & \multirow[b]{2}{*}{ Power } & \multirow{2}{*}{$\begin{array}{l}\text { BASIS OF } \\
\text { CHARGE }\end{array}$} & \multicolumn{2}{|c|}{ Custom Rate } & \multirow{2}{*}{$\begin{array}{c}\text { NUMBER } \\
\text { OF } \\
\text { RATES } \\
\text { INCLUDED }\end{array}$} \\
\hline & & & $\begin{array}{c}\text { Most } \\
\text { CомMON }\end{array}$ & $\begin{array}{l}\text { USUAL } \\
\text { RANGE }\end{array}$ & \\
\hline & & & Dollars & Dollars & \\
\hline Spreading lime & truck & ton & $0.75 \& 0.50$ & $0.50-1.00$ & 45 \\
\hline Spreading lime & team & day & - & $10.00-12.00$ & 3 \\
\hline Sawing lumber* & engine & 1000 B.F. & - & $10.00-15.00$ & 36 \\
\hline Saw cord wood & tractor & $\mathrm{hr}$. & - & $1.25-2.00$ & 7 \\
\hline Chain sawi & & hr. & 2.50 & & 3 \\
\hline Bulldozer & $22-25 \mathrm{hp}$. & $\mathrm{hr}$. & 5.00 & & 4 \\
\hline Bulldozer & $29-45 \mathrm{hp}$. & hr. & - & $6.00-8.00$ & 25 \\
\hline Bulldozer & $53-65 \mathrm{hp}$. & hr. & 10.00 & $10.00-12.00$ & 6 \\
\hline Post hole digging & tractor & hole & 0.10 & $0.10-0.30$ & 7 \\
\hline Hauling & team & day & 8.00 & & 5 \\
\hline Spray corn & airplane & acre & 3.25 & $2.75-3.50$ & 4 \\
\hline Spray corn & tractor & acre & $1.75 \& 2.50$ & $1.25-3.25$ & 8 \\
\hline Spray orchard & tractor & gal. & 0.01 & & 4 \\
\hline
\end{tabular}

*The number of men furnished varied from 1 to 7 .

†Two men furnished. 

